\title{
A CONTRIBUTION TO THE STUDY OF VALENCIAN LINGUISTIC SECESSIONISM: RELATIONS BETWEEN THE PERCEPTION \\ OF THE SUPRADIALECTAL UNITY OF THE CATALAN LANGUAGE AND OTHER SOCIOLINGUISTIC VARIABLES
}

JOSEP M. BALDAQUÍ ESCANDELL

\section{ABSTRACT}

This article is a contribution to the analysis of the phenomenon of Valencian linguistic secessionism. It analyses the methodological difficulties in studying this phenomenon and proposes ways to overcome them. It also presents the results of a study on the perception of the supradialectal unity of the Catalan language with other sociolinguistic variables: attitude towards the Valencian variety of Catalan, type of educational program (bilingual or monolingual), first language, Catalan or Castilian as predominant language), degree of Spanish self-affinity, degree of Valencian self-affinity, self-affinity to a linguistic group or social class.

The situation of the Catalan language in the Valencian Country is a very complex one, with an issue that must still be solved and remains on everyone's lips: linguistic secessionism. In this work we would like to present some data that facilitate the understanding of this question.

There are basically two kinds of sources dealing with the perception of the Valencian variety as a part of the common diasystem of the Catalan language: a) on the one hand, the surveys conducted annually by the Spanish Sociological Rescarch Centre (Centro de Investigaciones Sociológicas - CIS) which studies the social and political situation of the Valencian Country; ${ }^{\mathrm{I}}$ ) on the other hand, some approaches made from the field of Valencian sociolinguistic studies (Lluch and Salvador 1989, Colom 1998, Guardiola and Diéguez 1999), all conducted among young secondary students, and generally with limited samples.

From a methodological point of view, almost all these works use the survey as a method for obtaining data, and information is collected

I. Surveys for years 200r, 2002 and 2003 may be currently consulted on the CIS website (http://www.cis.es). 
by means of one single question or a limited number of questions whose responses are analyzed in isolation. ${ }^{2}$ Results show a heterogeneity of responses that may be at first attributed to the different geographical origin of the sample. When we carried out similar research, we encountered the same problem, which we analyze throughout this work in order to shed light on the methodology of the study of this subject matter (or at least to demonstrate the existing gaps).

Our work has been carried out among 13 and 14 year-olds in three cities of the L'Alacantí area, in the south of the Valencian Country. ${ }^{3}$ Our starting hypothesis was that the perception of the supradialectal unity of the Catalan language is a construct- a non-directly observable complex phenomenon, difficult to assess-which can only be studied by analysing the behaviour of individuals. For this reason we decided to use a Likert-type behaviour scale as an instrument for the analysis of this phenomenon.

We started from the eight items listed below in order to develop the Likert scale: 4

$\mathrm{I}^{\text {st }}$ item: Catalan and Valencian are the same language.

$2^{\text {nd }}$ item: Within the Catalan language, Valencian is a very important variety.

$3^{\text {rd }}$ item: The same language is spoken in Catalonia, the Valencian Community and the Balearic Islands.

\footnotetext{
2. In the case of surveys conducted by the CIS, the question is: "With regard to the identity of the Valencian language, which sentence do you identify with the most?" with identity of the Valencian language, which sentence do you identify with the most?" with from the Catalan language"; b) "It is the same language spoken in Catalonia and in the Balearic Islands"; c) "don't know"; d) "no response". The survey of Lluch and Salvador (conducted in the city of Valencia in 1986 ) used the following question: "Do you think that the Valencian language is the same language as Catalan and Majorcan, although it that the Valencian language is the same language as Catalan and Majorcan, although it
has its own varieties? "Colom's survey (conducted in the city of Valencia in 1994-1995) asked: "Do you think that the Valencian, Balearic and Catalan language are varieties of the same language?" The survey of Guardiola and Diéguez. (conducted in the Marina Baixa area in r997): "Do you think that the same language is spoken in Catalonia, the Balencian Country and the Balearic Islands?"

3. These three cities - Alacant, Mutxamel and Xixona- have very different sociolinguistic situations. According to the $200 \mathrm{I}$ census, the percentages of inhabitants sociolinguistic situations. According to the 200 I census, the percentages of inhabitants
who can speak Valencian are the following: Alacant: $27.3 \%$; Mutxamel: $46 \%$; Xixona: $76.3 \%$. Moreover, these cities have very different sociolinguistic characteristics: in Alacant the Catalan language is in a very precarious situation, in Mutxamel there is a latent confrontation between the two linguistic communities, and in Xixona the Catalan language has a higher social use.

4. It must be noted that the items were presented dispersed to the students (not in groups) within a longer questionnaire that evaluated the attitude towards the Valencian variety of the Catalan language. As is usual in the construction of this kind of scale, the respondents were to express their agreement or disagreement with each item on a 5 point scale: a) strongly agree; b) agree; c) don't know (or don't care); d) disagree; e) strongly disagree.
} 
$4^{\text {th }}$ item: Although Valencian and Catalan are currently very similar, they will become in the future more and more different, until they become two different languages.

$5^{\text {th }}$ item: The Catalan language is spoken in Catalonia, the Valencian Community and the Balearic Islands.

$6^{\text {th }}$ item: Valencian is a geographical variety of the Catalan language.

$7^{\text {th }}$ item: I think I will not understand the way of speaking of Majorca or Girona citizens, because it is very different to that of a Valencian.

$8^{\text {th }}$ item: The existing differences between Valencian and Catalan dialects will be more and more limited in the future thanks to linguistic normalization.

These items request the subjects' opinion about the supradialectal unity of the Catalan language, but they focus on different aspects of this topic:

a) The $\mathrm{I}^{\text {st }}$ item directly proclaims the identity of the two linguistic varieties.

b) Items 2 and 4 , which are similarly written, assert that Valencian is a variety within a common language, which is identified as the Catalan language. While the $6^{\text {th }}$ item only mentions a geographical variety, the $2^{\text {nd }}$ item describes Valencian as "a very important variety" within the Catalan language.

c) The $3^{\text {rd }}$ and $5^{\text {th }}$ items have similar content, as they identify the Catalan language with the main territories where it is spoken, but with an important difference: the $3^{\text {rd }}$ item does not mention the name of the language, although it explicitly says that it is the same language, whereas the $5^{\text {th }}$ item does specify that it is the Catalan language.

d) The $4^{\text {th }}$ and $8^{\text {th }}$ items refer to the future dimension of the Catalan language, concretely to whether linguistic evolution will contribute to an even greater unification of the varieties spoken in Catalonia and in the Valencian Country than the existing one, or to less unification, resulting in linguistic disintegration. The $4^{\text {th }}$ item formulates this idea in a negative way, and the $8^{\text {th }}$ item in a positive way.

e) Finally, the $7^{\text {th }}$ item refers to the polled perceptions of the impossibility of aural comprehension of some geographical varieties of the Catalan language (those of Majorca and Girona) that are further away from the respondents' own variety (Valencian).

Before further dealing with the construction of the Likert scale, we will analyse and comment upon the responses to each of the items mentioned above. The following table shows these results: 


\begin{tabular}{|c|c|c|c|}
\hline \multirow[b]{2}{*}{ ITEMS } & \multicolumn{2}{|c|}{$100 \%$} & \multirow[b]{2}{*}{$\begin{array}{l}\text { Neutral } \\
\text { value }\end{array}$} \\
\hline & $\begin{array}{c}\text { Positive } \\
\text { value }\end{array}$ & $\begin{array}{c}\text { Negative } \\
\text { value }\end{array}$ & \\
\hline Catalan and Valencian are the same language. & $38.2 \%$ & $61.8 \%$ & $13.1 \%$ \\
\hline $\begin{array}{l}\text { Within the Catalan language, Valencian } \\
\text { is a very important variety. }\end{array}$ & $78.1 \%$ & $21.9 \%$ & $35.7 \%$ \\
\hline $\begin{array}{l}\text { The same language is spoken in Catalonia, } \\
\text { the Valencian Community and the } \\
\text { Balearic Islands. }\end{array}$ & $36.8 \%$ & $63.2 \%$ & $33-2 \%$ \\
\hline $\begin{array}{l}\text { Although Valencian and Catalan are } \\
\text { currently very similar, they will become } \\
\text { in the futuremore and more different, until } \\
\text { theybecome two different languages. }\end{array}$ & $39.8 \%$ & $60.2 \%$ & $45.7 \%$ \\
\hline $\begin{array}{l}\text { The Catalan language is spoken in Catalonia, } \\
\text { the Valencian Community and } \\
\text { the Balearic Islands. }\end{array}$ & $41.9 \%$ & $58.1 \%$ & $37.7 \%$ \\
\hline $\begin{array}{l}\text { Valencian is a geographical variety } \\
\text { of the Catalan language. }\end{array}$ & $69.3 \%$ & $30.7 \%$ & $36.2 \%$ \\
\hline $\begin{array}{l}\text { I think I will not understand the way of } \\
\text { speaking of Majorca or Girona citizens, } \\
\text { because it is very different to that } \\
\text { of a Valencian. }\end{array}$ & $57.6 \%$ & $42.4 \%$ & $27.6 \%$ \\
\hline $\begin{array}{l}\text { The existing differences between Valencian } \\
\text { and Catalan dialects will be more and more } \\
\text { limited in the future thanks to } \\
\text { linguistic normalization. }\end{array}$ & $55.3 \%$ & $44.7 \%$ & $52.8 \%$ \\
\hline
\end{tabular}

TABLF I: Responses to the items about the unity of the Catalan language

Table I shows the response percentages to the questionnaire items related to the unity of the Catalan language. In order to interpret this table it is necessary to take into account the following: a) the column on the right, described as the "neutral value," shows the percentage of the people polled that answer "I don't know, or I don't mind" and also those who do not answer the question; b) the other two columns show the positive or negative responses to cach item without taking into account the "neutral" responses (for this reason, the total is $100 \%$ ). The responses to the negatively formulated items were recodified so that the "positive value" column shows in every case a favourable opi- 
nion on the supradialectal unity of the Catalan language, and the "negative value" column shows a negative opinion. ${ }^{5}$

As can be seen in the table, there is a rather clear tendency towards indefinition, whose usual values are around $30 \%$, and even beyond $45 \%$ when students are asked to make predictions about the futurc of the language. The favourable responses to the statement that the Valencian variety belongs to the common diasystem have in some cases high values ("Within the Catalan language, Valencian is a very important variety" $[78.1 \%]$ and "Valencian is a geographical variety of the Catalan language" $[69.3 \%]$ ), and very low values in other cases ("The same language is spoken in Catalonia, the Valencian Community and the Balearic Islands" [36.8\%] and "Catalan and Valencian are the same language" $[38.2 \%])$.

In fact, what is observable is that when the items refer to Valencian as a linguistic variety, the responses are much more positive as a whole than when an identification of varieties within the same language is simply mentioned.

One of the studies we mentioned before, that of Ferran Colom (1998: 155-159), analyses the awareness of the supradialectal unity of the language among third-year secondary students and first-year students at a technical college in the city of Valencia ${ }^{6}$ from a single question within a sociolinguistic questionnaire. This item was "Do you think that Valencian, Balearic and Catalan are varieties of the same language?" and three responses were accepted: a) Yes; b) No; c) I do not know. The results obtained by Colom show that, in general, most of the students $(62.4 \%)$ were of the opinion that these three dialectal varieties are part of a common linguistic diasystem, ${ }^{7}$ while $13 \%$ of students thought that these are not varieties of the same language; a high percentage of students $(24.7 \%)$ do not define their position about an issue described by Colom as "socially controversial" (Colom 1998: 156).

If we compare the results obtained in our study with those obtained by Colom, the first remarkable difference is that Colom's results show a more positive view about the supradialectal unity of the Catalan language, but it is necessary to point out that in his item Valencian,

5. That is, the "positive values" are the response percentages "agree" or "strongly agree" in the case of the positively formulated items, and "disagree" or "strongly disagree" in the case of ncgatively formulated items. The "negative values" are the response percentages "agree" or "strongly agree" in the case of negatively formulated items, and "disagree" or "strongly disagree" in the case of positively formulated items.

6. These two educational levels are equivalent with regard to age. The majority of these students were between $16(55.2 \%)$ and $17-18$ years of age $(35.6 \%)$. Colom worked with a total sample of 877 students interviewed during the 1994-1995 school year (Colom 1998: 51-55).

7. Special mention must be made of the degree of coincidence between the results for this utem obtained by Lluch and Salvador (1989) and Colom (1998). 
Catalan and Balearic are identified as varieties of the same language, without mentioning the name of said language. In our questionnaire, the questions that identify Valencian as a linguistic variety are also those with the most positive responses. We believe, however, that in our study the consistent identification of Valencian as a linguistic variety of the Catalan language has an influence on these results, whereas in the item in Colom's study, Valencian, Balearic and Catalan are mentioned as varieties of the same language without mentioning its name (Colom 1998: 206), which may increase the percentage of positive responses.

Reflections about the contrast between the results of Colom's work and those of this study may lead us to formulate a number of methodological suggestions that should be taken into account in future studies:

a) Firstly, it is necessary to point out that the way of formulating items has a decisive influence on the results, particularly when information is sought about attitudes. For example, speaking about languages or linguistic varieties has a major influence on the responses of those polled. Even mentioning or not mentioning the name of the common language appears to influence the responses.

b) Secondly, we think that these differences show the difficulty of assessing perceptions of the unity of a language by using a single question. This is the reason why we consider that the construction of scales is a more adequate method to judge this phenomenon.

c) Thirdly, we think that the perception of the supradialectal unity of a language may be a multidimensional construct with several factors, such as conceptualization as languages or as varicties, identification or nonidentification with a common name, projection towards the past or the future of the unity of the language, interdialectal comprehension, etc. ${ }^{8}$

d) Consequently, we consider that the preparation of an evaluation system of this phenomenon (possibly a scale) would be appropriate if it had an adequate reliability and enough consensus in the scientific community for use in future research, in order to obtain comparable results.

\section{CONSTRUCTION OF A SCALE OF PERCEPTION OF THE SUPRADIALECTAI} UNITY OF THE CATALAN LANGUAGE

In order to construct a Likert-type scale of the awareness among students of the supradialectal unity of the Catalan language we have started from the eight items we described above. The procedure consists

8. For more information about the question of languages as a mental construct, see Calaforra (1999: เ27). 
of the analysis of the integration of items within the scale from two statistics: the corrected correlation between each item and the total, and the value of Cronbach's statistical alpha if the item is removed.?

Finally, only three items remain in the scale, but although there is a limited total number of items, we have obtained an adequate total reliability $(\alpha=0.7426)$, because it is very close to 0.75 , which is usually and conventionally accepted. ${ }^{10}$ In the end, the items forming part of our scale are the following:

- The same language is spoken in Catalonia, the Valencian Community and the Balearic Islands.

- The Catalan language is spoken in Catalonia, the Valencian Community and the Balearic Islands.

- Catalan and Valencian are the same language.

According to our initial hypothesis, the perception of the Valencian variety as a part of the common diasystem of the Catalan language was a complex construct, but the results of the scale construction contradict this hypothesis, since there are only three variables that form part of the scale of the unity of the Catalan language, and besides, they are very similar. In order to avoid this uncertainty, we engaged in an analysis of principal components and we concluded that this is a one-dimensional scale."

RELATIONSHIP BETWEEN THE PERCEPTION OF THE SUPRADIALECTAL UNI'TY OF THE CATALAN LANGUAGE AND OTHER SOCIOLINGUISTIC VARIABLES

We then analysed the relationship between the new variable-the measure of students' attitude towards whether the Valencian variety belongs to the common diasystem of the Catalan language-and other

9. This study is a part of a wider research project. For more details about the preparation of the scale and generally about the statistical analysis mentioned in this article, see Baldaquí $2003^{\text {a. }}$

Io. Morcover, we should bear in mind that Cronbach's statistical alpha depends not only on the correlation between items, but also on the number of items, and therefore if the number of items increases and maintains a constant average correlation, the value of the statistical alpha would also increase (Arce 1994: 37).

II. It should be noted that the data at our disposal are not very suitable to engage in a principal components analysis. The results of the analysis show, however, that there is a principal components analysis. The results of the analysis eigenvalue higher than $\mathrm{I}$, and that the three variables forming part of the scale have high saturations $(0.85536,0.81193$ and 0.77286$)$ in this single dimension of the opinion on whether the Valencian variety belongs to the common diasystem of the Catalan language. 
outstanding sociolinguistic variables also analysed in our study. The following table summarizes the most interesting results:

\begin{tabular}{|c|c|c|}
\hline \multirow[t]{2}{*}{ VARIABLE } & \multicolumn{2}{|c|}{$\begin{array}{l}\text { OPINION ON WHETHER THE } \\
\text { VALENCIAN VARIETY BELONGS TO } \\
\text { THE COMMON DIASYSTEM OF THE } \\
\text { CATALAN LANGUAGE }\end{array}$} \\
\hline & $\mathrm{F}-\mathrm{r}-\chi^{2} \mathrm{I2}^{2}$ & Significance $F-r-\chi^{2}$ \\
\hline $\begin{array}{l}\text { Attitude towards the Valencian variety } \\
\text { of the Catalan language (Likert scale) }\end{array}$ & $r=0.3892$ & $\mathrm{p}<0.00 \mathrm{r}$ \\
\hline Type of educational program & $F_{3,193}=4.4660$ & $p=0.0047$ \\
\hline First language & $x^{2}=6.8757$ & $\mathbf{p}=0.0296$ \\
\hline Linguistic predominance ${ }^{4}$ & $f=0.3127$ & $p<0.001$ \\
\hline Degree of identification with Spain & $r=-0.268$ & $\mathrm{p}=0.0001$ \\
\hline Degree of identification with Valencia & $r=0.180$ & $\mathrm{p}=0.0 \mathrm{r} 33$ \\
\hline Identification with a linguistic group & $F_{2,194}=5.3590$ & $P=0.0054$ \\
\hline Social class & $F_{3,193}=5.7094$ & $p=0.0009$ \\
\hline
\end{tabular}

TABLE 2: Relations between the perception of the Valencian variety as a part of the common diasystem of the Catalan language and other sociolinguistic variables.

12. According to the nature of the data, different statistical tests were used: analysis of variance (statistic F) or Pearson corrclations (statistic $r$ ). In a case in which parametric supposition could not be proved we used Kruskal-Wallis $\mathrm{H}$ test with figure chi-square $\left(x^{2}\right)$ in order to calculate the significance level. We can interpret significance as the probability of making a mistake in the interpretation of relations between the mentioned variables. In social sciences it is generally accepted that the significance level should be lower than 0.05 , that is, that the probability of making a mistake in our interpretations should be inferior to $5 \%$. As we can see in the table, all relations we are commenting on have an associated significance lower than this value.

13. For details on the construction of this attitude scale, see Baldaqui 20or: 138-143.

14. For details about the way of analyzing linguistic predominance of the Catalan or Spanish language, identity and linguistic identification of the population studied, see Baldaquí 2003 b: $17-50$. 
The analysis of relations between the perception of the supradialectal unity of the Catalan language and various social and linguistic variables of the study show that the perception of the unity of a language is related to linguistic attitudes, educational programs, first language, linguistic predominance, identity, identification with a linguistic group, and social class. Further interpretation of these results indicates that the groups of young people with a higher perception of the unity of the language are the students with the best linguistic attitude, those who take bilingual educational programs, those with Catalan as first language or with bilingual families, those who prefer the Catalan language and mainly consider themselves Valencian speakers, those who feel nearer to the Valencian identity (and more distant from the Spanish one), and those with higher social background, and, therefore, those who are members of families with a higher educational level. These results were foreseeable, and hence they confirm what could easily be expected. What we would like to comment on here is an interesting issue we discovered when analysing the relations between the attitude towards the Valencian variety of the Catalan language and the awareness of the supradialectal unity of the language.

In the table we can see that the correlation between the attitude towards the Valencian variety of the Catalan language and the students' opinion on whether this variety belongs to the common linguistic diasystem is a positive one, with moderate intensity and statistically significant $(r=0.3892 ; \mathrm{p}<0.001)$.

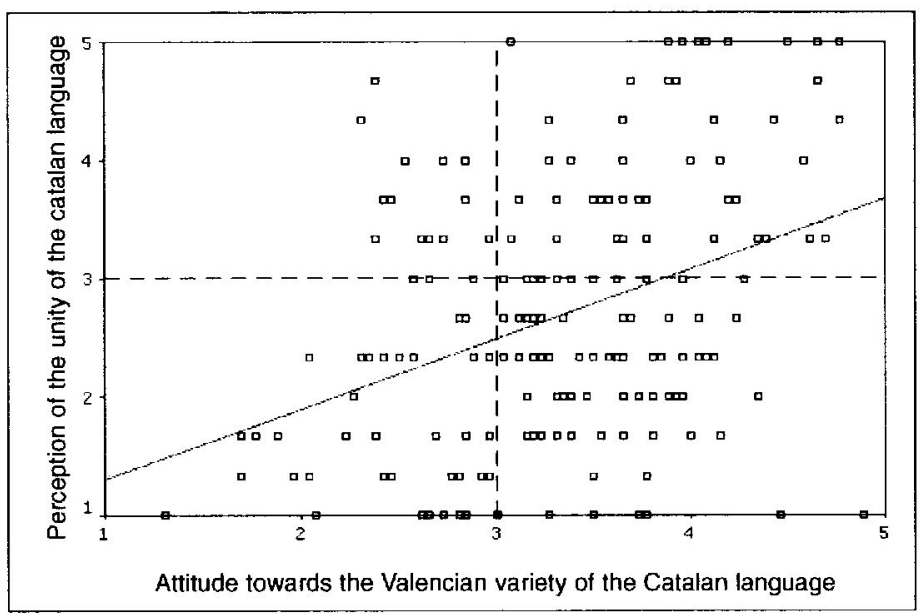

GRAPH I: Correlation between linguistic attitude and perception of the unity of the language 
The dispersion graph (Graph I) shows that points between the two variables may range from 1 to 5 . The broken reference lines in neutral points (3) help to confirm that there are few students with a positive opinion of the supradialectal unity of the language who have at the same time attitudes towards this language that may be described as negative (top left-hand quadrant). However, there are many more students with a positive attitude towards the Catalan language and a negative perception of the unity of this language (lower right-hand quadrant).

Therefore, it seems that a positive perception of the unity of the Catalan language is quite incompatible with a negative attitude towards this language, but not the other way round, since a positive attitude is possible towards the Valencian variety coexisting with a negative perception of the unity of the language. In any case, it should also be considered that statistical analysis results show that, although there is a non-random relation between the attitude towards the Valencian variety and the perception of linguistic unity, linguistic attitude is a factor that explains a small amount (I5.I5 \% $)^{\text {I5 }}$ of the variance of the opinion on whether the Valencian variety belongs to the common diasystem of the Catalan language.

The finding that linguistic attitude explains a relatively unimportant part of the perception of the unity of a language was foreseeable; it should not surprise us, nor should it be viewed unfavourably. On the whole, attitudinal studies usually reveal that the capacity of attitudes to explain other factors is usually low, and this is usually attributed to the relatively abstract and generic nature of attitudes, generally measured with a much lower precision value than that of the behaviours we try to explain (Baker 1995: 16). From our point of view, another more interesting question is how to interpret the compatibility that appears to exist between the positive attitude towards the Valencian variety of the Catalan language and the lack of awareness of the supradialectal unity of language.

In keeping with the results of previous work (Guardiola and Diéguez 1999), our hypothesis is that it is a subject related to the cognitive dimension of attitudes. ${ }^{16}$ Specifically, some of the main causes of the anomalous and schizophrenic situation in which Valencians live with

I5. The square of coefficient $r$ is 0.1515 . The coefficient of $r$ squared represents the proportion of variation in a variable explained by its linear association with another variable (García Ferrando I992: 278).

16. As is well known, nowadays the majority of attitude definitions state that they present a multiple component structure. These definitions greatly agree that attitudes would consist of three dimensions: cognitive, affective and behavioural or conative. For an up-to-date revision of this matter see Moreno Fernández (1998: 182-189). 
regard to our linguistic identity are the lack of explicit information on the Catalan language, its different geographical varieties, the name, etc., in addition to the policy of ambiguity, or even of deliberate confusion, on this subject both in political spheres and in the media. The Department of Education has even censored school textbooks with actions such as prohibiting certain words because they were considered to be too "Catalan," as well as maps where the complete linguistic area of the Catalan language was depicted. ${ }^{17}$

JOSEP M. BALDAQUÍ ESCANDELL UNIVERSITAT D'ALACANT/IIFV

\section{WORKS CITED}

ARCE, Constantino. Técnicas de construcción de escalas psicológicas. Madrid: Síntesis, 1994.

BAKER, Colin. Attitudes and Language. Clevedon: Multilingual Matters, 1995 (Ist repr.).

BALDAQUí ESCANDELL, Josep M. Una mesura de l'actitud lingüística en alumnes escolaritzats en programes educatius bilingües. Actes del Novè Colloqui d'Estudis Catalans a Nord-Amèrica. Eds. August Bover i Font, Maria Rosa Lloret i Mercè Vidal-Tibbits. Barcelona: Publicacions de l'Abadia de Montserrat, 200r: 133-156.

- Els programes educatius bilingües a la comarca de l'Alacantí. Estudi Sociolingüistic. Alacant: Fundació Biblioteca Virtual Miquel de Cervantes, $2003^{\mathrm{a}}$. [CD-Rom]. This study may be consulted on the Internet page: <http://www.cervantesvirtual.com/FichaObra. html? Ref $=8877>$

- Avaluació sociolingüística dels programes valencians d'ensenyament bilingüe. Llengua, Societat i Ensenyament vol. I. Eds. Vicent Martines et ai. Alacant: Institut Interuniversitari de Filologia Valenciana, $2003^{\mathrm{b}}$ : $17-50$. This study may be consulted on the Internet page: <http://publicaciones.ua.es/LibrosPDF/84-608OoI5-6/I-02.pdf >

Calafforra, Guillem. Paraules, idees $i$ accions. Reflexions "sociologiques" per a lingüistes. València - Barcelona: Institut Interuniversitari de Filologia Valenciana - Publicacions de l'Abadia de Montserrat, 1999. 
Centro de Investigaciones Sociológicas. Estudio $n^{\circ}$ 2413. Situación social y politica de la Comunidad Valenciana (VIII). Madrid: CIS, 2001.

- Estudio $n^{\circ}$ 2445. Estudio sociológico de la Comunidad Valenciana. Madrid: CIS, 2002.

- Estudio $n^{\circ} 248$. Estudio sociológico de la Comunidad Valenciana. Madrid: CIS, 2003.

COlOM ORTIZ, Ferran. El futur de la llengua entre els joves de València. Coneixement, ús $i$ actituds lingüistiques en els joves estudiants de la ciutat de València. València: Denes Io, 1998.

GARCla FERRANDO, Manuel. Socioestadística. Introducción a la estadística en sociologia. Madrid: Alianza, 1992 (4th repr.).

Guardiola i Savall, Maria Isabel and Maria Angels Diéguez Seguf, Els jóvens de la Marina. Estudi sociolingüistic. Alacant: Club Universitario, 1999.

LLUCH, Gemma and Vicent SALVADOR. Enquesta sobre actituds sociolinguiístiques entre els estudiants d'un institut de la ciutat de València. Segon Congrés Intermacional de la Llengua Catalana. VII : Area 6. Ensenyament. Ed. Joan Martí i Castell. Tarragona - Reus: II Congrés Internacional de la Llengua Catalana, 1989: 360-363.

Moreno Fernández, Francisco. Principios de sociolingüística y sociologia del lenguaje. Barcelona: Ariel, 1998. 